Regards sur l'économie allemande

Bulletin économique du CIRAC

116-117| 2015

Varia

\title{
Accidents de la route : différences de culture
}

Isabelle Bourgeois

\section{OpenEdition}

Journals

Édition électronique

URL : http://journals.openedition.org/rea/4831

DOI : 10.4000/rea.4831

ISSN : 1965-0787

Éditeur

CIRAC

Édition imprimée

Date de publication : 1 juillet 2015

Pagination : 72

ISSN : 1156-8992

\section{Référence électronique}

Isabelle Bourgeois, «Accidents de la route : différences de culture », Regards sur l'économie allemande [En ligne], 116-117 | juillet 2015, mis en ligne le 01 juillet 2017, consulté le 15 septembre 2020. URL http://journals.openedition.org/rea/4831

Ce document a été généré automatiquement le 15 septembre 2020.

(c) CIRAC 


\title{
Accidents de la route : différences de culture
}

\author{
Isabelle Bourgeois
}

Malgré une légère hausse depuis 2013 (29 de plus ; Destatis), le nombre de tués sur les routes allemandes (3 368) figure en 2014 parmi les plus bas depuis 1950. En France, l'Observatoire national de la sécurité routière (Onisr) compte 3384 tués $(+116)$. En comparaison européenne, la mortalité routière est faible en RFA avec 42 tués pour un million d'habitants, alors qu'en France, elle est dans la moyenne (52). Ce qui distingue les deux pays, en l'absence d'une analyse comparée fine de la mobilité, de l'équipement des ménages ou du réseau routier, ce sont les raisons officiellement avancées pour expliquer cette hausse: en France, "la vitesse», concept absolu; en Allemagne, la donnée factuelle des conditions météo qui, quand elles sont clémentes, accroissent le trafic, surtout des deux roues, particulièrement vulnérables, sans parler des piétons. Quant à la politique de sécurité routière : répressive en France, considérant l'usager comme un justiciable, en Allemagne, elle est avant tout préventive, misant sur l'information des citoyens et leur responsabilité (voir www. bmvi. de). Un exemple concret illustrant les différences de culture politique et citoyenne...

INDEX

Mots-clés : Comparaison franco-allemande, démographie, statistique, transport 